\title{
被服廠跡に生じた火災旋風の研究
}

\author{
相 馬 清 二* \\ Study on the Fire-Tornado at the Former Site of the \\ Hifukusho (the Army Clothing Depot)
}

Seiji SOMA

\begin{abstract}
A violent fire-tornado has broken out at the former site of the Army Clothing Depot in combustion caused by the destructions of the Great Kanto Earthquake at 3.30 p.m. September 1, 1923. By this fire-tornado, about 40 thousand people have been burned to death in a moment. An interpretation that the fire-tornado has been caused by passage of a cold front has generally dominated academic circles in this field up to date. According to the detailed reexaminations, this interpretation included many inconsistencies. We could obtain recently the various data with respect to the fire-tornado which occurred in the last several years. From these data, it became clear that the firetornadoes often have occurred near a combustion area.

An example which was the most similar with the fire-tornado at the former site of the Army Clothing Depot was found out in the combustion of Wakayama City by an air raid on July 9, 1945. 748 persons have been burned to death by the fire-tornado in this city.

Finally, our study leads to the conclusion that the fire-tornado at the former site of the Army Clothing Depot was caused by the widespread great fire following the Great Kanto Earthquake. There was a cold front in northwestern direction of Tokyo, but it did not play the leading role for formation of the fire-tornado.
\end{abstract}

はしがき

大正 12 年 9 月 1 日, 関東南部を襲つたマグニチュード 7.9 の大地震は首都東京をはじめ 横浜, 川崎の大 都市に潰滅的な打撃を与えた。地震規模は必ずしもかが国最大なものではなかつたが，人口のもつとも稠 密な市街地带に起こり，しかも大火災を誘発したため，世界の災害史上でも例を見ない大災害となつた。 火災は 2 日間にわたつて燃え続け, 東京だけでも50万戸のうち30万戸が灰盢に帰したといわれている。ま た, 死者, 行方不明合わせて 10 万人近くに達し, 目を覆うような惨状が市内の各戸にくり拡げられた。中 でも，旧本所区(現在の隅田区)の陸軍被服廠跡では，その区画内だけで 3 万 8 千の避難民が，一瞬の間に 焼きつくされるといら大惨事があつた。このことは関東大震災の中でも象徴的な惨事として，いまなお多 くの人々によつて語り伝えられている。

* 気象研究所物理気象研究部

Physical Meteorology Laboratory, Meteorological Research Institute 


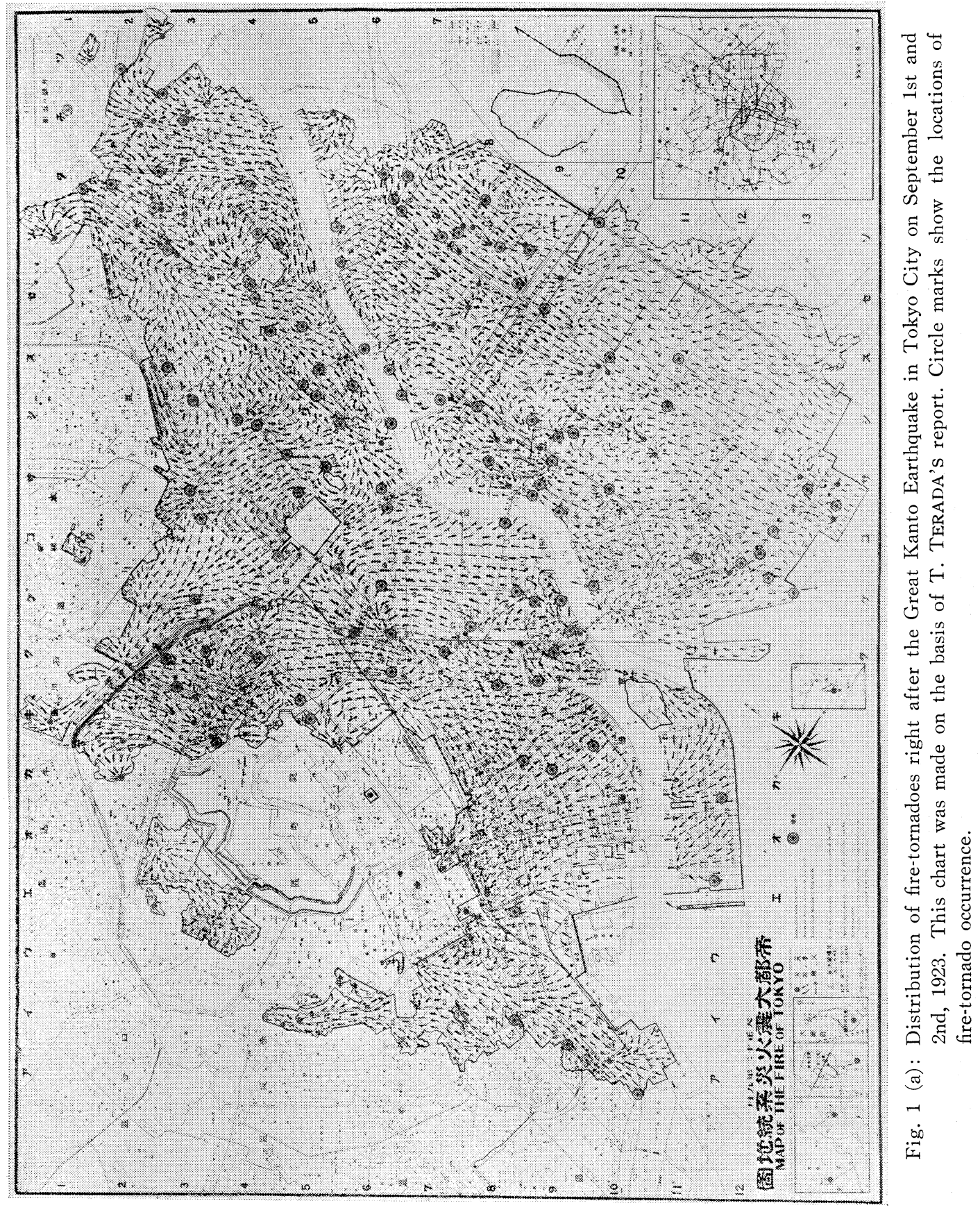




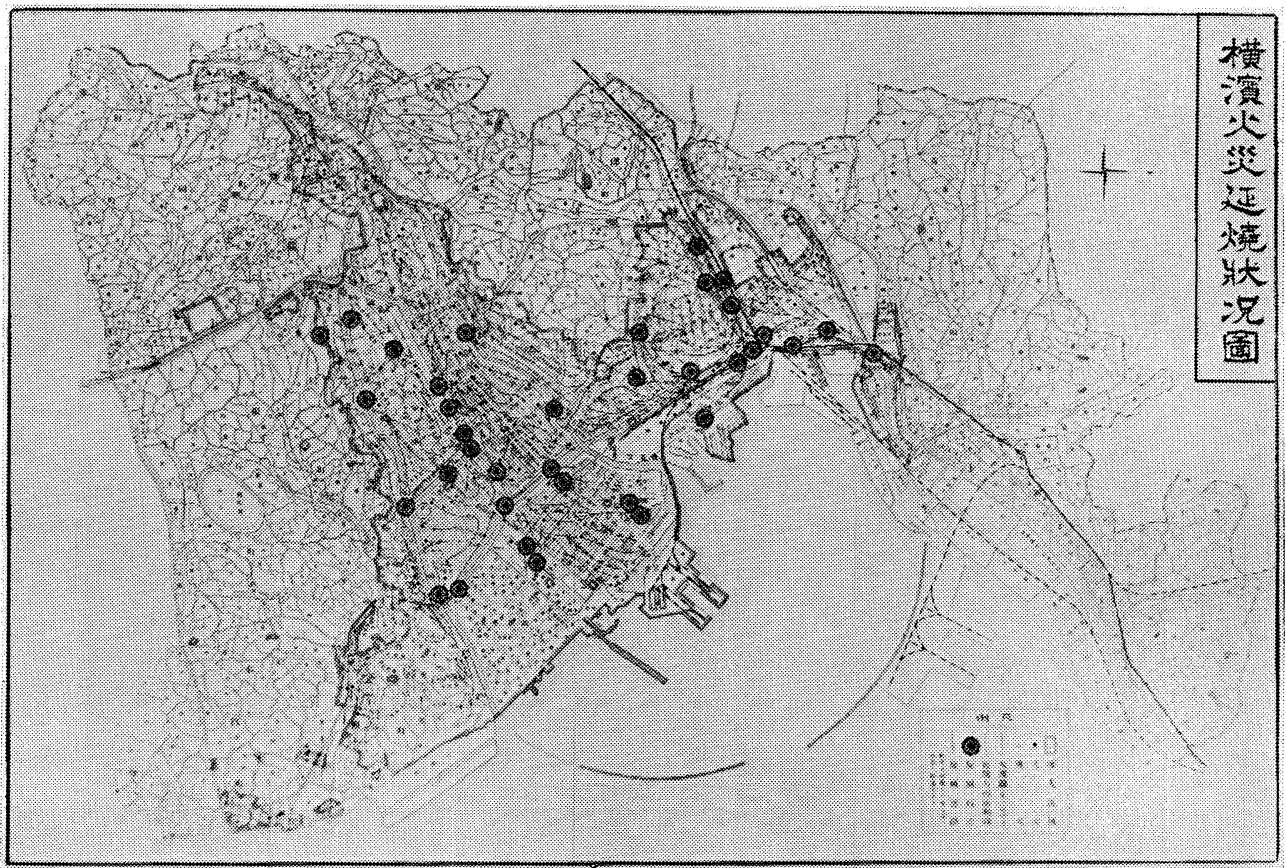

Fig. 1 (b): Distribution of fire-tornadoes right after the Great Kanto Earthquake in Yokohama City on September 1, 1923. This chart was made on the basis of S. FuJIWARA's report. Circle marks show the locations of fire-tornado occurrence.

被服廠跡にこの惨事をもたらしたものは，烈風の中に火の粉を抱えこんだ竜巻であつたという。竜巻と いうのは，自然界の中でも，もつとも烈しい現象の一つで，それに伴う風速は $100 \mathrm{~m} / \mathrm{s}$ を越すことも稀で はない。しかし，その発生頻度は年間約 10 ケ位であって，そう頻度の高いものではない。このような現 象がどうしてあの時点で被服廠跡に発生したのか, これに対して, これ迄の研究では菓巻は不連続線の通 過に伴つて発生したという解釈で片ゔけられていた。この解釈によると，あの惨事は大火災に，気象の 極端な現象が偶然に重なつたために生じたということになる。果してこの解釈のままでよいのだろう か，関東大地震の再来が社会の大きな関心事となつている現在，この問題を再検討してみる必要があつ た。

\section{I. これ迄の研究の概要}

\section{1. 既往の調查および用語の問題}

この異様な現象は学界でも注目され，東京大学教授寺田寅彦(1925)，中央気象台技師藤原咲平(1924)な ぞ当時の鋝々たる学者によつて，惨事後ただちに調查が進められた。これらの調查結果は震災予防調查会 報告第100号戊 (大正 14 年 3 月発行) および 関東大震災調查報告気象編 (大正 13 年 8 月中央気象台発行) その 他傽細に報告されている。

寺田寅彦教授は前述の報告書の中で，“旋風” は被服廠跡だけでなく，これ以外の地域でも発生し，9 月 1 日から 2 日にかけて約100ケにも達したと述べている(第1図(a))。また，藤原咲平博士は，大地震後 の火災によつて横浜にも30ケ近くの“旋風”が発生したと報告している（第1図(b))。ここで注意したい のは，両氏共に単に“旋風”という用語を用いていることである。現在での一般的な通念からすれば，他 にいろいろな要因があっても，火災が主因となって発生したものは火災旋風と呼ばれることになる。しか 
し，50 年前の調查報告書の中で，火炎旋風という用語を使わなかつたのは，旋風の主因は火災ではないと 考えたためか，あるいは，当時まだこの用語が確立していなかつたことによるのか，その辺のことは判燃 しない。何れにしても専門用語のことは将来の論議に委䄈ることにするが，ただ，当時の一般の人々は竜 巻と呼んでいたようである。子供の頃, この現象に遭遇したという現回向院住職本田清敬氏は，『両親達 は確か竜巻と言つていたような気がする』と述べている。この報告書においても，火災旋風と竜巻の両方 を混同して使用した。しかし，結論においては，発生原因から推して，その何れであるかを明確にしてい る。

\section{2. これ迄の解釈}

被服廠跡の竜巻の発生原因について, 中央気象台刊行の関東大震災調查報告（気象編）には“午後 4 時 ないし 5 時頃，隅田川に沿つた被服廠跡に起りたる旋風は不連続線通過に伴いて起りたる現象なり”，と明 記されている。この解釈が連綿と現在まで続き, 学界の大勢を制していた。ただし，つい最近になつて， あの竜巻は台風に伴う Outer Rain Band (外圈降雨帯) 内に生じた, という説をなすものもある。Outer Rain Band も不連続線の一種であるので，この解釈も不連続線説の範ちゆうに入れて差し支えないむの であろう。

\section{3. 不連続線説に対する遅疑}

本調査は，まず，不連続線説の因つてきたる 処を詳細に調べ直すことから始めた。大正12年 9 月 1 日，竜巻が発生した当時の天気図をみる と, 確かに, 群馬県南部に北東から南西に伸び る不連続線が存在していた(第 2 図)。竜巻が不 連続線近傍に発生し易いといらことは, 今日で は常識となつているが, 当時としては, 比較的 斬新な知識であつたろう。したがつて，これと 被服廠跡の竜巻とを結びつけた解釈は極めて受 け入れ易いものであつたに違いない。しかしな がら，正確を期して，天気図の資料を関係気象 官署へ照会し，改めて天気図を見 直してみる と，不連続線説に対していろいろな疑念が生じ てくる。

まず 9 月 1 日午後 4 時, 埼玉県熊谷測候所の 天気は晴であり，また，前橋測候所では雲量 3 で快晴に近い天気であつた。東京では，午後 4 時には, 雲量 6 で晴であつた（第 3 図）。つま り，当時の天気図を風だけを念頭においてみた 処では, 不連続線の存在はかなりはつきりして いるが, しかし, 以上の天気, 雲量の面から検討 すると，雲量が極めて少なく，天気が良過ぎる 感じがする。最近の研究によれば，大気の成層 不安定が童巻発生の基本条件であると云われて いる。そして成層が不安定であれば，必然的に 雲は生じ易く, 雨となる場合も多いのである。 雲量が少ないといらだけで, 自然の竜巻の発生

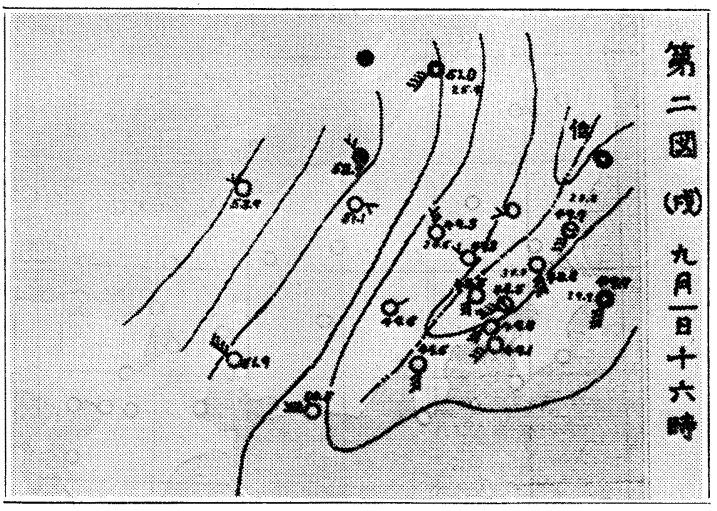

Fig. 2 Weather chart at 4 p.m. on the day when the fire-tornado occurred at the former site of the Army Clothing Depot. The fire-tornado occurred at 3.30 p.m. on that day (September 1, 1923).

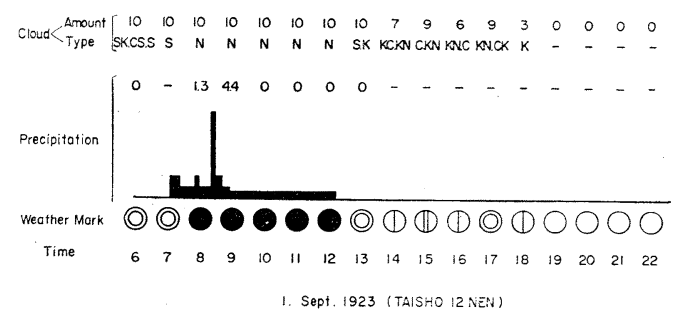

Fig. 3 Change of weather, amount of cloud, cloud type and precipitation on the day of the Great Kanto Earthquake. 
を否定し去ることはできないが，この程度の不連続線を竜巻に結びつけることは無理であろう。

この天気，雲量，降水量等の資料は童巻が Outer Rain Band に発生したとする説に対しては一層不利 なものとなる。Outer Rain Band 内に竜巻が発生する率は確かに高い。しかし, その名が示すように, そ

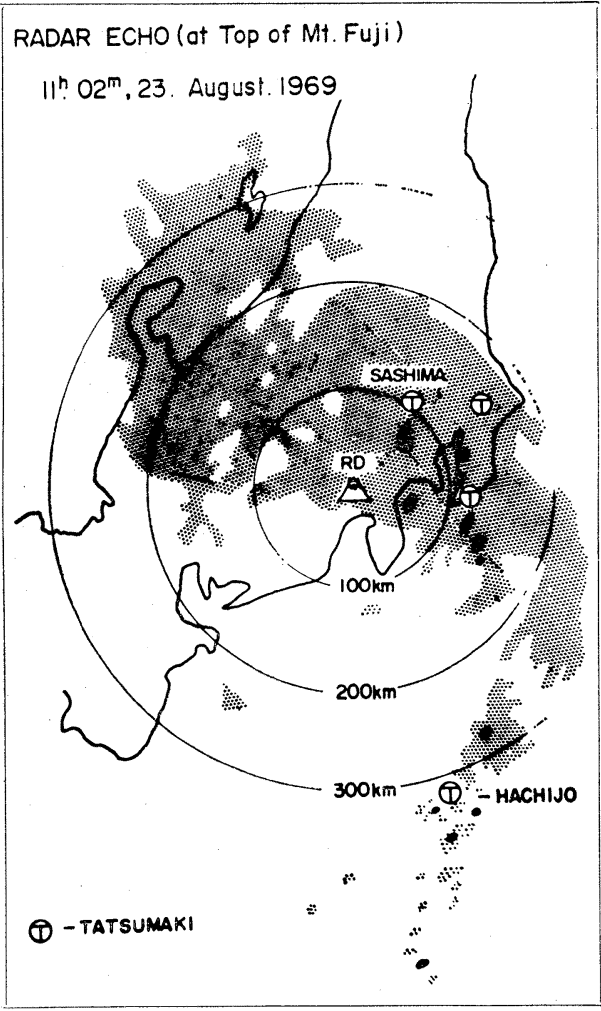

Fig. 4 An example of meteorological tornadoes which occurred in passage of an outer rain band.

の区域全般で雨が降つていることが多い。一例を挙げれ ば，昭和 44 年 8 月 23 日に関東中部から八丈島へかけて烈 しい童巻が殆ど同時刻に 4 ケも発生したことがあつた。 そのさいは，この地帯に細長く，しかも顕著な Outer Rain Band が形成されていた (第 4 図)。大正12年 9 月 1 日午後 4 時頃には不連続線はあつたが，その近傍には 雨らしい雨はなかつた。

\section{II. 被服廠跡の竜巻の実龍}

天気図あるいは気象条件に竜巻発生の原因を帰し得な いとすれば，他にそれを求めなければならない。しか し，それを追求する前に被服廠跡に生じた竜巻とは，一 体どのようなものであつたか，その実態を詳しく調べる 必要がある。

\section{1. 竜巻の強度 (風速)}

被服廠跡を襲つた風がきわめて強烈なものであつたこ とは，生き残つた被災者の陳述からある程度推測でき る。しかしそれだけでは風の量的な資料としては不充分 である。幸いに，風による被害を示す写真が報告書の中 に掲載されていたので，それから竜巻の風速を推算して みた。写真 1 の左は震災報告書の中に掲げられていたも ので, 直径 $30 \mathrm{~cm}$ 以上の樹木が引き裂かれるように切 断されている。これとよく似た樹木の切断写真（写真 1 の (b) 一筆者撮影) が昭和 46 年 7 月, 埼玉県大宮市郊外の 竜巻の被害地域において得られた。気象研究所の渡辺和 夫（1971）が調查した処では，この竜巻の強度は $F_{3}$ 階 級のものであつたという。因に, $\mathrm{F}_{3}$ 階級の風速範囲は 70.4 92.5m/s である。両写真の比較から, 被服 廠跡を襲つた竜巻は大宮市郊外のものとほぼ同じ強度のものと考えて差し支えない。すなわち，被服廠跡 では，竜巻によつて $80 \mathrm{~m} / \mathrm{s}$ 前後の烈風の吹いたことはほぼ間違いない。

\section{2. 竜巻の形状}

一般的な表現であるが，自然の竜巻は母雲からロート状に垂れ下がり，場合によつてはその尖端が地面 に接するといら形状を呈する。被服廠跡の竜巻は一体どのような形状をしていたのであろうか，古い報告 書によつてそれを調べてみた。

被服廠で 38,000 人が焼死したが，猛烈な風と火焰に苛まれながら，辛うじて助かつた人は少くとも 2,000 人位はいた。この人達には目のあたりに竜巻と対峙していた一瞬があつた筈である。また，大地震 直後の混乱状態にあつたとは云え，隅田川の対岸からこの現象を見ていた人も少なからずいたに違いな い。わずか $150 \mathrm{~m}$ の川幅にすぎないので，竜巻の形状の観察はある程度可能であつたように考えられる。

古い報告書の中から，竜巻の形状に関する陳述例を一，二拔粋してみよう。まず，被服廠跡の惨事に遭 遇しながら，辛うじて難を免がれた近藤二郎二氏の陳述によると『午後 3 時半頃と党ゆる時，空一杯に高 


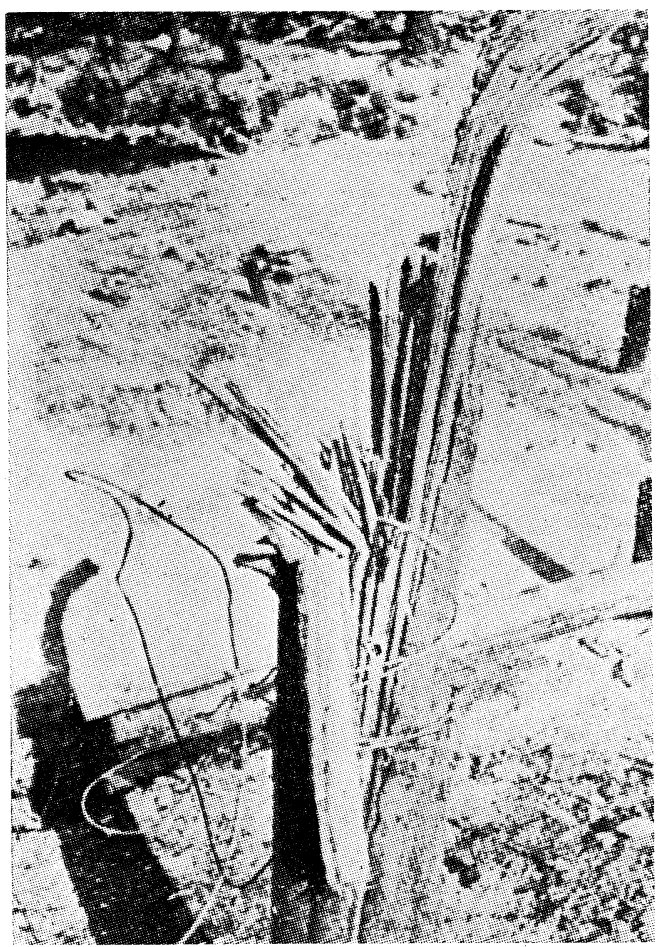

Plate 1 (a): A tree torn off by the firetornado. This was taken at the former site of the Army Clothing Depot right after the Great Kanto Earthquake.

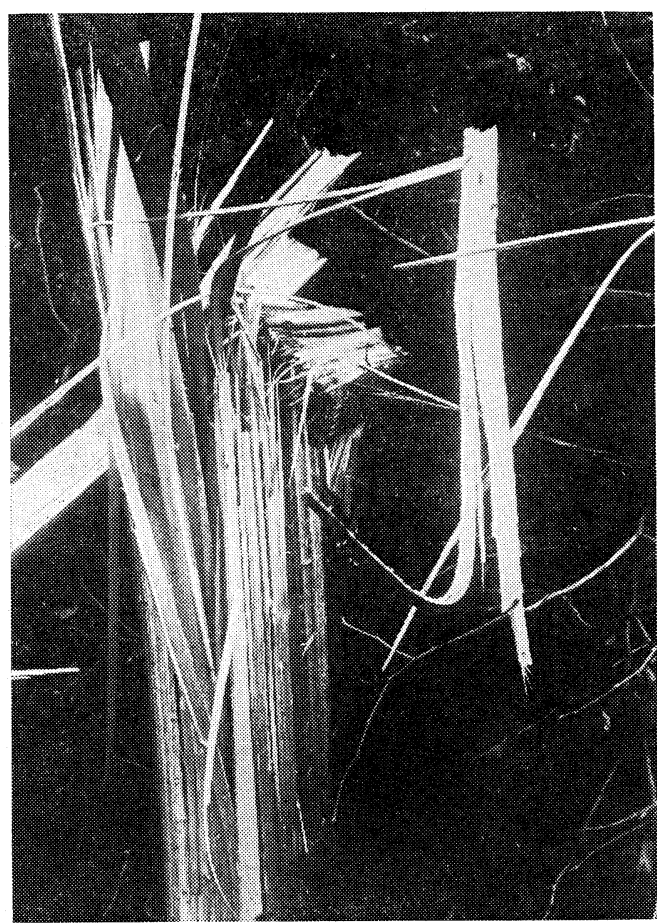

Plate 1 (b): A tree torn off by the meteorological tornado. This was taken at the suburbs of Omiya City, near Tokyo on 7th July, 1971.

く煙の昇りくるを見たり，ようやくにして，天暗くなるに及んで，われも人も煙に巻かれ枋るにあらずや と不安を感じ, 大丈夫かと語り合う間もなく, 南方よりバリバリと大音響を立つると共に, 強風来畩, 火は 点々と荷物につく…』。また, 被服廠跡の南方約 $700 \mathrm{~m}$ に位置する回向院広場から竜巻の状況を観察した 川鍋健二氏の談話によると，『3 時半頃北方にあたり，バリバリと何物かを打ちこわす大音響聞こゆ，その 音次第に強く，これは津波と言い，火薬に火がっきたりと言い，何れも定かならず。その辺り墨を流せる ごとき小山の高さにてうず巻き，その物凄さ言語に絶す…ㄹなっている。

これらの陳述は，それぞれ被服廠跡の童巻を部分的に表現しているに過ぎない。しかしながら，『空一 杯に高く煙の昇りくるを見たり』あるいは『黒き小山の高さにてうず巻き』などの表現をつなぎ合わせて 見ると，後述の火㷪旋風の実例によく似た形状ができあがる。また川鍋氏の陳述は，自然の竜巻が地面に 接した場合の状況と極めてよく似ている。

\section{3. 惨事の経過}

東京大学中村清二教授による火災動態図を用いて，竜巻が発生した 9 月 1 日 3 時半 4 時頃の 火災延焼 状況をみると，その時点では，まだ東京全市が然えていた訳ではなかつた。しかし，旧本所区において は，隅田川に沿つた被服廠跡の空地を残して，南北に約 3,000m. 東西に約 $1,600 \mathrm{~m}$ の広大な地域が延焼 していた。見方を変えれば，約 $70,000 \mathrm{~m}^{2}$ の被服廠跡の空地は，その何倍も広い火災地带に囲まれていた のである。その空地に約40,000の避難民がひしめき合つていた。しかも, 人々はその中で, 安心し切つて 食事したり，その夜をしのぐ準備をしていた。あるいは隅田川の满々たる水に何らかの信頼感を寄せてい 
たのかも知れない。誰一人として，竜巻の来襲を予想したものはいなかつた。

一大ごう音と共に竜巻が来襲し, 群集の頭上と, 持ち込んだ家財道具に火の粉をばらまいた。火は強風 に煽られ，被服廠跡はたちをち火の海になつた。竜巻が荒れ狂つたのは，わずか20分間と云われ，文字通 り瞬時の間に $38,000 人 の$ 命運はつきたのである。隅田川の川面は烈しく波立つていて，障害にこそなれ惨 事の軽減にはあまり役立たなかつた。

被服廠跡の惨状の模様をいちいち羅列する訳にはいかないが，古い報告書の中に，火災旋風による被害 の特徴を示す現象が目についたので，それを一つだけことにとりあげよう。

近藤二郎二氏の談によると，『火焰は地を低く這い廻つた。人々は焰を飲んで倒れた…』を，『火 傷もせず，無きずのまま助かつたが，二三日後に胸が痛いと言つて死んだ・...』とある。似たような陳述 はほかにも二，三みられる。中田金市博士編 “火災”（1969）によれば，高温の煙による肺呼吸性の熱傷は， その死亡率がきわめて高いという(第 1 表)。このような熱傷では，第一段階として肺胞毛細管の破綻によ る呼吸不全, 続いて肺水腫が主病変となつて，この時期を克服しても細菌性肺炎を引き起こして，そのほ とんどが死亡するに至る。

第 1 表 気道熱傷による死亡率

\begin{tabular}{|c|c|c|c|}
\hline & 死 & 亡 & $(\%)$ \\
\hline $\begin{array}{c}\begin{array}{c}\text { 露出時間 } \\
\text { (分) }\end{array} \text { 呼気温度 } \\
\end{array}$ & $70^{\circ} \mathrm{C}$ & $80^{\circ} \mathrm{C}$ & $90^{\circ} \mathrm{C}$ \\
\hline 5 & 0 & 0 & 0 \\
\hline 6 & 0 & 0 & 0 \\
\hline 7 & 0 & 0 & 0 \\
\hline 8 & 0 & 0 & 40 \\
\hline 9 & 0 & 0 & 100 \\
\hline 10 & 0 & 20 & 100 \\
\hline 11 & 0 & 80 & 100 \\
\hline 12 & 0 & 100 & 100 \\
\hline 13 & 20 & 100 & 100 \\
\hline 14 & 40 & 100 & 100 \\
\hline 15 & 100 & 100 & 100 \\
\hline
\end{tabular}

中田金市博士編“火災”より

被服廠跡の場合では，開放された野外での火災であり，しかも，烈風によつて焰は地面を䑛め䞟した。し たがつて焰を吸うことが比較的多かつたのではないかと考えられる。近時，ビル火災などの場合に，煙に よる窒息死の多いことが報じられているが，火災旋風による死亡経過はこれと若干異つた様相を呈する。

\section{4. 竜巻の移動方向}

竜巻がどのような移動方向を辿つたか。一見単純と思われる事柄であるが，これは被服廠跡の竜巻が気 象条件のみによつて発生したのか, あるいは他の原因によるものかを決める重要なカギとなる。最近の研 究によると，第 2 表に示されるように，不連続線の通過または台風の Outer Rain Band 内に生ずる竜巻 は, 大体に括いて南象限から北象限に向かつて移動する。また, 竜巻は一般流に流されて移動するため, 地上の一般流とほぼ同じ方向を辿る。若干のずれがあるとしても，60 度以上も方向がくい違うことはまず ない。

さて, 被服廠跡の竜巻の移動方向がどうであつたか，震災報告書を調べてみると，これに触れている陳 述は案外多い。しかしながら，一般の人の陳述には，自分に吹き当る，いわば地上風向と竜巻系全体の移 動方向とを混同していることが多い。藤原咲平博士はこのような混同を考慮して，陳述の取捨選択を行な 
第 2 表 自然の竜巻の移動方向

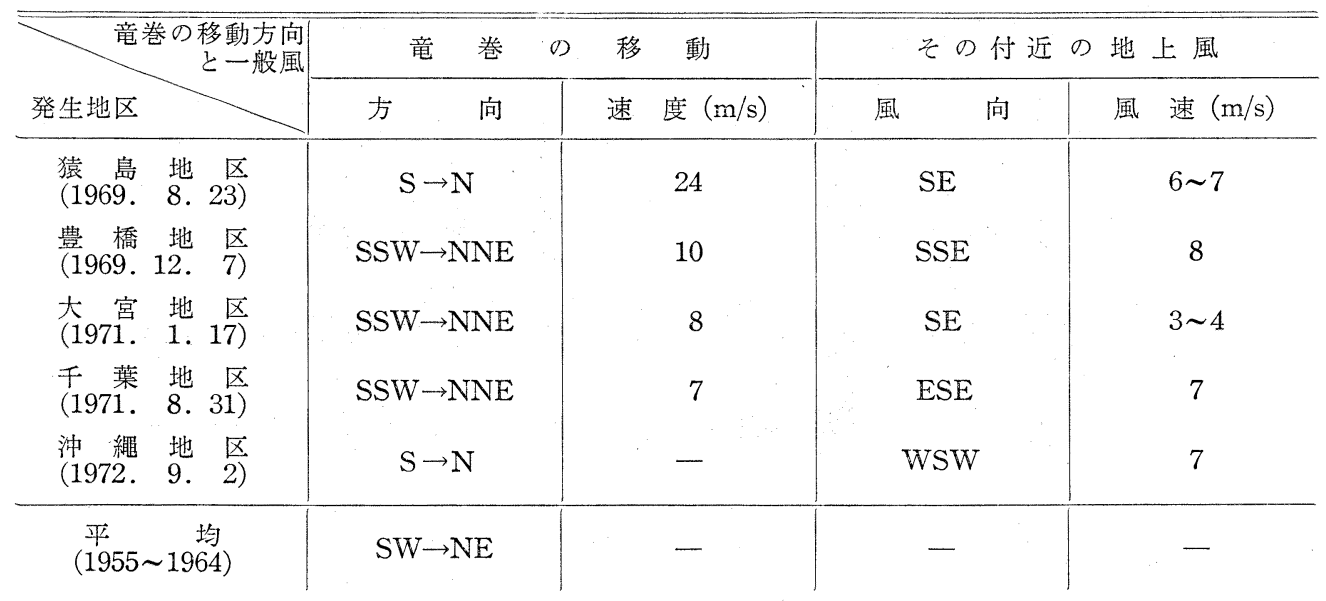

い，かつ総合判断して竜巻系全体の移動方向をつぎのように推定した。

『以上の状況より判断すると, 被服廠跡の惨劇の 原因たる 竜巻は, 北番場町の 南端にて急に激烈とな り，そこょり厩橋と被服廠跡の間，すなわち外手町，石原町，横綱町を注瞬時に猛火に包み，被服廠跡に殺 到したるものにして, 恐らく番場町南端にて起りたる竜巻は廐橋をかすめ, 川に沿うて横網町の安田邸付 近に至り，東に巻き返し石原町にて数個合して，さらに北東より被服廠跡に 戻り来たりしものならんか』 この推定に基づいて竜巻の移動方向を図上で辿つてみると，ほぼ北東から南西に向かつて移動したことに なる。前述したように，自然の竜巻でこのような方向を辿つたものは，わが国では今までに観測されたこ とがない。さらに問題な点は, 被服廠跡の竜巻は当時の地上風向と反対な方向を辿つていることである。 震災当時, 中央気象台㧤よび品川信号所の何れの観測でも, 南寄りの風が吹いていた。このことは, 被服 廠跡の竜巻が自然の気象条件によつて発生したものとは著しく違つたものであることを示唆している。

\section{III. 火災に伴う竜巻の実例}

諸外国の災害史を調べてみても，数万の人を焼死せしめたといら大規模な火災旋風の例は見当らない。 しかし，火災原因を地震だけに限らないで，しかも小規模なものを含めて数えあげて見ると第二次大戦以 後艺けでもかなりの数に達する。

(i) 1961年 6 月, フランスの雲物理学者 J. DESSENS（1962）がピレネー山麓の高原地帯で, 熱気流に よつて積雲を作る実験を行なつた。かなり大がかりな実験で $125 \times 125\left(\mathrm{~m}^{2}\right)$ の広い範囲に48本の石油バー ナーを据え, これをいつせいに燃やして熱気流を作つた。燃燒面積が広いため, 焰と黒煙が壮大に拡がつ た。その際，まったく予期しないことに，燃焼域の風下に竜巻が発生した（写真 2 の(a)）。写真に示され た処によると, 燃焼域から $525 \mathrm{~m}$ 離れた風下に, 直径 $10 \mathrm{~m}$, 高さ $200 \mathrm{~m}$ にも達する竜巻が形成された。 注意して観察したところ，竜巻はその後もしばしば発生したという。

（ii）また，1967年の秋，米国のアイダホ州汇総面積50,000エーカーに及ぶ大規模な山火事が発生した。 その山火事を拡大したのは，竜巻がつぎからつぎへと発生し，それが火の粉を風下へ運んで点火したため と報告されている(第 5 図)。

（iii）わが国でも火災の周辺で竜巻が発生した記録がある。昭和 40 年 5 月北海道室蘭港において，ノル ウェーの大型タンカー $(56,000 \mathrm{t})$ が接岸に失敗して船腹に大穴をあけた。そこから流出した原油に火がつ いて大火災になつたことがある。その際にも，風下に顕著な竜巻が発生した(写真 3 )。

(iv) 昭和21年12月21日, 南海沖大地震（マグニチニード8.1）のさいに，和歌山県新宮市に火災が発生 


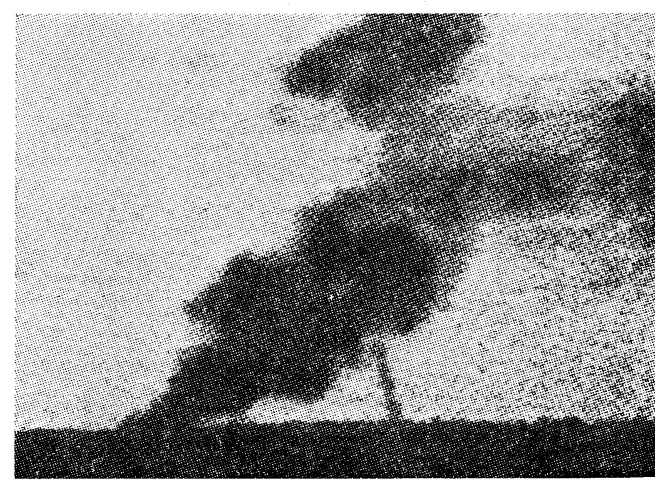

Plate 2 (a): Artificial fire-tornado made accidentally in the lee of a large scale fire plume at the outdoor (by J. DESSENS, 1961).

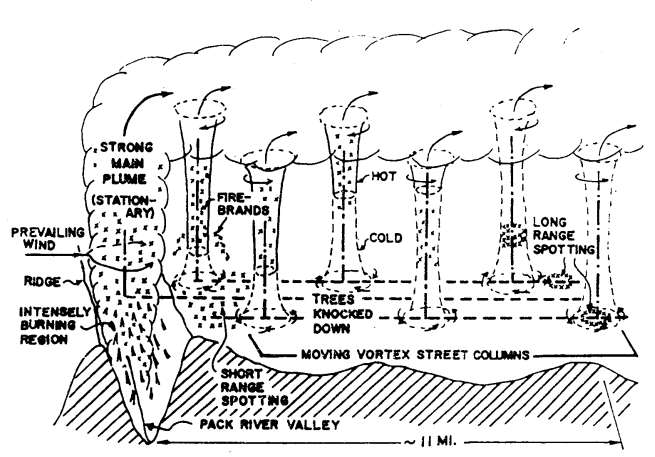

Fig. 5 Sketch of Sundance Fire flow model.

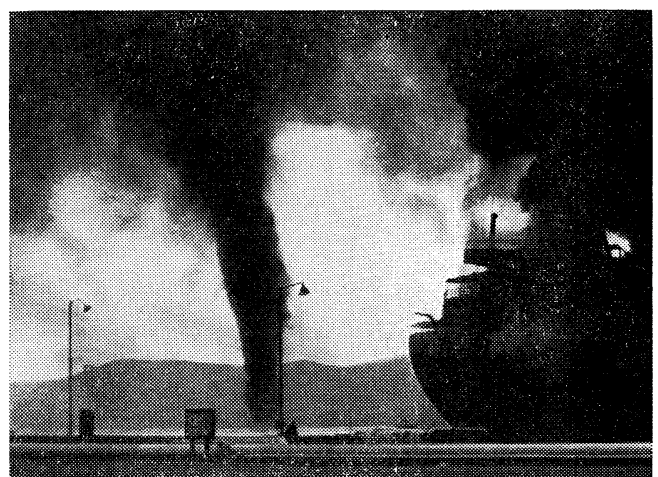

Plate 3 Fire-tornado which occurred in the lee of a burning tanker $(56,000 \mathrm{t})$ near Muroran Port in Hokkaido, 1965. (Provided by Hokkaido Newspaper)

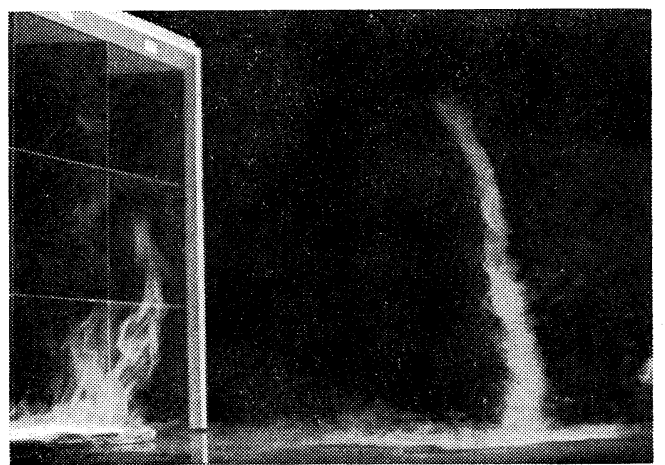

Plate 2 (b): Vortex column like a fire-tornado in laboratory (by S. SoMA, 1973).

し，市街地の $25 \% ， 2,612$ 戸が 焼失する大火となつ た。火災は朝出火し，夕方まで続いたが，その日の 午後に竜巻が発生したといら報告がある（奥田穣， 1973)。竜巻はそれ程強いものではなかつたが，そ れでも疊（重さ約 $22 \mathrm{~kg}$ ）を舞いあげる強い風速を 伴なつていた。

\section{IV. 和歌山市の火災による竜巻}

前述に較べてはるかに大規模な竜巻が第二次大戦 の空襲による大火災の際に発生している。昭和 20 年 7 月 9 日の真夜中, 米爆撃機 B 29 による空襲は和歌 山市を猛火に包み，その $68 \%$ を焼失させた。その 際，市の中心部にあたる旧県庁跡の空地に激しい竜 巻が起こり，748名を焼死させた。焼死者の数は被 服廠跡の惨事には遠く及ばないが，この数は当夜の 空襲による全死者の 6 割強の高率にいたつており， 竜巻による惨事の恐ろしさを示している。

和歌山市戦災史(1956)から，当時の惨状の一部を 収録してみよう。『焼夷弾により大火災が起つてか ら30〜40分経つた頃，物凄い火災旋風が市内各所に 起つた。この中で最も凄烈な竜巻は旧県庁跡の南方 約 $200 \mathrm{~m}$ の電車通りに巻きおこり，北に向け進ん だ。火焰はフイゴで吹かれた火のように白熱して横 になびいた。お濠端の松並木は全部折れ飛んだ。ど こかの自動車は土堤をのり越えて濠の中へ飛び込 み，また背したトタン板や，太さ一抱えもあるよ らな木材が 20〜30m も高く舞い上がつた…』。 
これとは別に旧県庁跡から約 $1,500 \mathrm{~m}$ 西南西の方 向にあたる湊鼠島でも，同夜火災旋風が発生して いる。『この島の海軍木材集積場には, 約10万本 という大量の木材が積み重ねられていたが，それ に火がついて大部分が焼失した。旋風に吹きあげ られて，無数の焼けた材木が赤い小さい箬棒のよ うに沖天高く舞い上がつた。これが乱れとんで， 築地橋辺りに避難した人々を警かせた…』。和 歌山測候所の観測によれば，当夜10時には東北東 $2.5 \mathrm{~m} / \mathrm{s}$ の弱い風であつた。

竜巻発生時刻にもつとも近い 7 月 9 日18時の天 気図を参照した処，和歌山市周辺一帯は天気快晴 で, 不連続線その他, 自然の竜巻が発生するよう な気象条件河も見い出されなかつた(第6図)。 戦災史には，竜巻がもたらした風速は $30 \mathrm{~m} / \mathrm{s}$ 位 と書かれているが，松並木の折損，木材の飛散状 況から推定すると，実際にはこれよりはるかに強 い風ではなかつたかと考えられる。

また，同資料の中に，自動車が吹き飛ばされた といら記述があるが, 最近における強風と自動車 被害の研究を参照すると, $30 \mathrm{~m} / \mathrm{s}$ の風速では, 自 動車が土堤をのり越こえることはできないようで ある。

\section{V. 震災時の雲}

中央気象台の古い観測原簿によると, 9 月 1 日 16時には積乱雲が観測されていた。被服廠跡上空

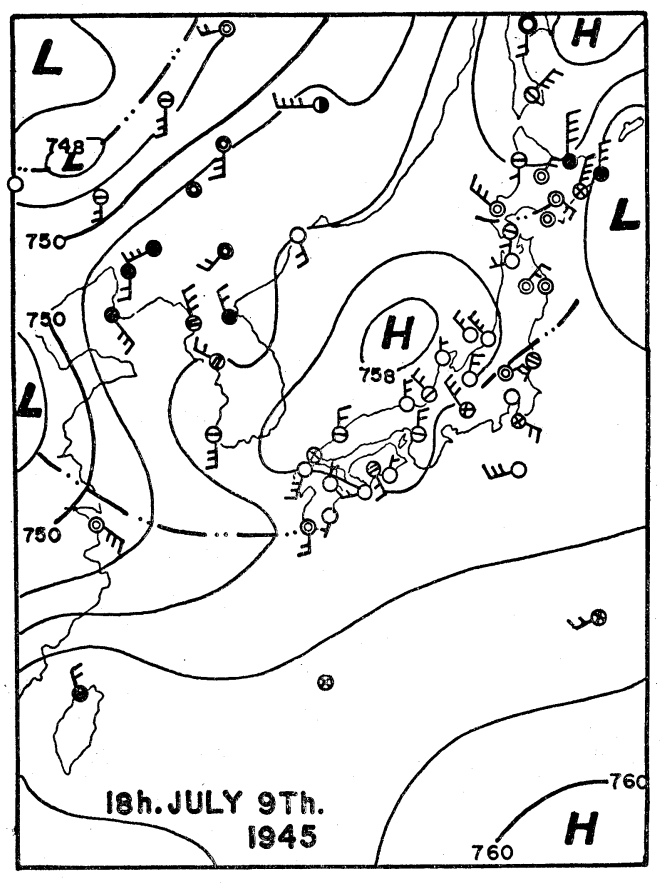

Fig. 6 Weather chart at 6 p.m. on the day when Wakayama City was burned by an air-raid. There was no front around the Wakayama district, and the weather was fine over a wide area around this district. The fire-tornado occurred under this weather condition.

にも，この種の雲がかかつていたことはほぼ間違いない。震災報告書の中の『小雨がパラついてきたの で, 雨戸やむしろで雨覆いの準備とした』という記事はこれを裏付けるものであろう。気象台の原簿に は，単に積乱雲とだけしか書かれていないが，この時の雲は極めて異様な形をした積乱雲であつたようで ある。この雲は多くの人の注目を引き，震災報告書の中にもこれに関する記事は多い。その中から，寺田 寅彦教授による雲の描与をここに引用しょう。

『9 月 1 日午後 3 時半頃, 著者は駒込曙町の自宅の縁側に立つて, 東南の 空に発達する顕著な積雲を眺 めていた。雲の表面は一見して普通の積雲と違つた特徵を示していた。すなわち, 表面の粒状突起が細 く, きわめて鮮明であつて, その肌合いは丁度先年桜島噴火のときの噴煙の写真を思い出させた。それが 青く澄んだ晴れた空に盛り上がっている状況は，未だかつて見たこともない光景であつた…』。ちなみ に，被服蔽跡は駒込曙町の位置からすれば，丁度東南の方向に当つている。したがって，この異様な積雲 が被服廠跡上空にあつたものと考えることができる。

震災資料の中に，原田三夫氏が撮つた積乱雲の写真が聥入されている(写真 4 )。この雲が被服廠跡の上 空にかかつていたものかどらかは明らかでない。しかし，その異様な形状は寺田寅彦教授の描写そのまま のような感じがする。筆者の気象観測の経験から推しても，この雲の容貌は確かに異常である。単に異常 というだけでなく，巨大なエネルギーが爆発したような迫力を感じさせる雲である。この雲の形成に，湿 


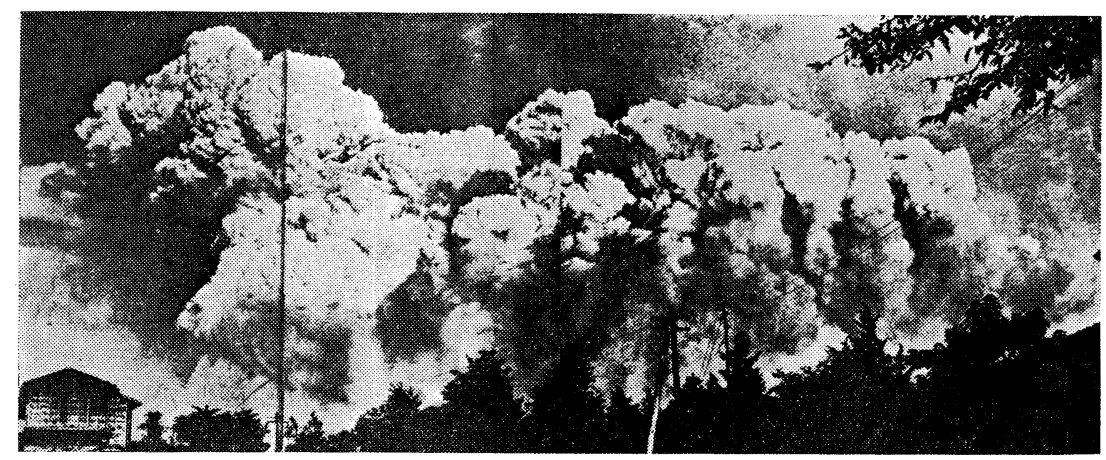

Plate 4 Gigantic cumulonimbus in the sky over Tokyo right after the Great Kanto Earthquake (taken by M. HARADA). The former site of the Army Clothing Depot seems to have been covered by such a cumulonimbus at that time of fire-tornado occurrence.

潤な小笠原気団と不連続線付近の成層不安定が若干寄与していたかも知れない。しかし，その主要原因 は，広域大火災によつて生じた大気の成層不安定エネルギーにあるとした方が，むしろ自然であろう。

\section{VI. 実験的研究}

火苂域の周辺に竜巻の発生する事例はかなり多く見い出されたが，どらして童巻が形成されるのか，そ の具体的なメカニズムはまだ明らかではない。竜巻発生当時の気象その他の資料によつて，このメカニズ ムを研究することは，竜巻発生環境の特殊性からいつて実際上不可能に近い。このため，著者は次善の策 と考えられる実験的手法によつて，この研究を行ならことにした。実験はをだ充分でなく，定性的な結果 を得たに過ぎない。中間報告的な段階であるが，ここにそれを述べう。

\section{1. 実験装置}

まず，実験装置を簡単に説明しょう。この主要部分は，地表になぞらえた直径 $2 \mathrm{~m} の$ 円型の 金属基盤 々，水平ならびに鉛直何れの方向にも任意の風速分布を与え得る風洞から成つている（写真 5 ）。金属基盤 の下部には樑さ $25 \mathrm{~cm}$ 直径 $2 \mathrm{~m}$ の水槽が取りつけられており, 槽内の水は加熱されるようになつている。 つまり，水の温度を調整することによつて，金属基盤上における気層の不安定度がいろいろ変えられるよ らになっている。また，風洞は，よこ 5 列，たて 3 段併せて15ケの送風口を持つており，夫々が個々にフ

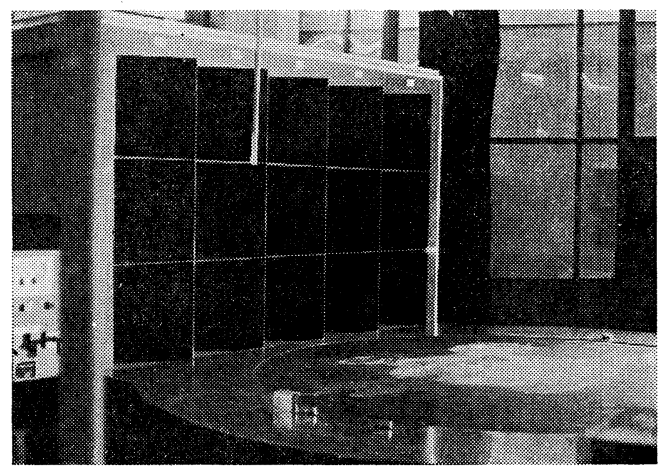

Plate 5 Aparatus for the experimental study of a pfire-tornado. Vortex column like fire-tornado are made on the round coper table.
アンを備えて任意の風速を出せる構造になつてい る(写真 5 )。

\section{2. 円型燃焼域の実験}

最初に，金属基盤上に市街地燃燒域をもつとも 単純化した円型燃焼板を置いて実験を行なつた。 然焼板は厚さ $10 \mathrm{~mm}$, 直径 $600 \mathrm{~mm}$ のガラスウ ールから成つたものであり，それに然料としてエ チルアルコールをしみ込ませてある。これに点火 した後, 側面の風洞から風を送り, 燃焼域周辺の 気流がどのように変化するかを観察した。

まず，風洞ファンをとめて，風を全く与えない 実験では, 然焼域周辺の気流は, 燃焼域に向かつ て収斂するだけで，特に変わつた気流現象は見ら れない。つぎに，風洞ファンの回転数を最大にし 
て, 強い風(約 $5 \mathrm{~m} / \mathrm{s}$ )を送ると，火焰は横になび く。しかし，周辺の気流には取りたてて述べる程 の変化は見られなかつた。最後に, 風速を徐々に 下げて, 適度な風速 (ここでは約 $1 \mathrm{~m} / \mathrm{s})$ を与える と, 燃焼域の風下に竜巻状の渦柱の立ち上がるの が観察された(写真 $2(\mathrm{~b}))$ 。この渦柱法直径数 $\mathrm{cm}$. 高さ $1 \mathrm{~m}$ 位で，一般流に流されてゆつくり然焼 域から遠ざかつていつた。風速条件を適当保て ば，この渦柱はつぎからつぎへと形成された。

この現象は形成条件から云つて, フランスの DESSENS が野外の火㷋実験で見出した竜巻と本 翼的に同じもと考えられる。渦柱が全体とし て焰の方向に傾く傾向があるが，この点も DESSENS の野外実験での竜巻とよく似ている。

\section{3. 逆 L 字型燃焼域}

被服廠跡周辺における市街地延燒形状を極端に 単純化すると，英語の大文字Lを肉厚にして，左 右反転した形と見做すことができる。この延焼形 状が竜巻発生の一つの条件ではないだろうかとの 想定から，これに似た形状の然焼板について前述 と同様の実験を行なつてみた。形状が非対称なの で, 風速条件とは別に, 風向きもいろいろと変え て実験を行なつた。結果的には，被服廠跡に竜巻 が発生した場合と似たような風向条件にすると， 丁度, 被服廠跡の空地に対応する位置に, 顕著な 竜巻状の渦柱が見られた（写真 6 (a) (b))，（第 7 図)。この洞柱は 円型燃燒板上で形成されたもの とは異なつて，一般風に流されることはなく，大 体において空地に相当する位置で旋転していた。 風洞からの送風条件にもよるが，一般風に逆らつ て進むこともあつた。燃焼域の面積が倍加された ためと思われるが，円型燃燒板の場合よりも，こ の方が渦柱の規模が大きく，かつ強烈なものであ つた。詳細に観察すると，烈しく旋転している渦 柱は，右側の長方型燃焼板上の焰を吸い込んで， 焰を横になびかせることがあり，また，渦柱がこ の燃燒板へ入り込んで火焰の竜巻とでも称すべき 火柱を形成することがあつた。

\section{VII. 地震火災の特徵と竜巻}

これらの実験結果は, 被服廠跡に生じた竜巻が 広域大火災によるといら解橎に, 一つの裏付けを

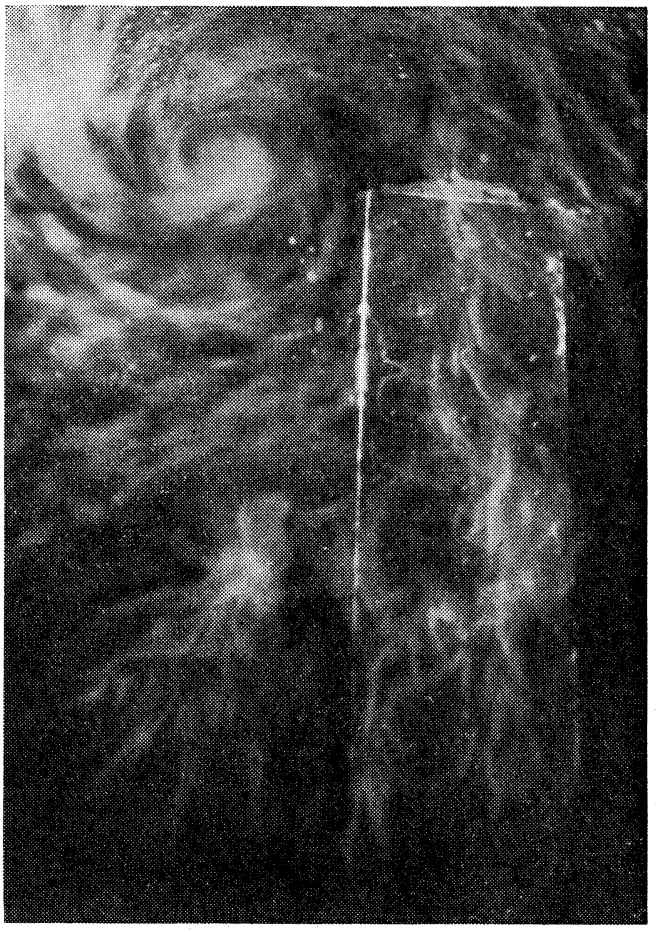

Plate 6 (a): Vortex column like a fire-tornado obtained by the burning area model of reversed "L" type. Vortex column can be seen on upper left. This picture was taken from above.

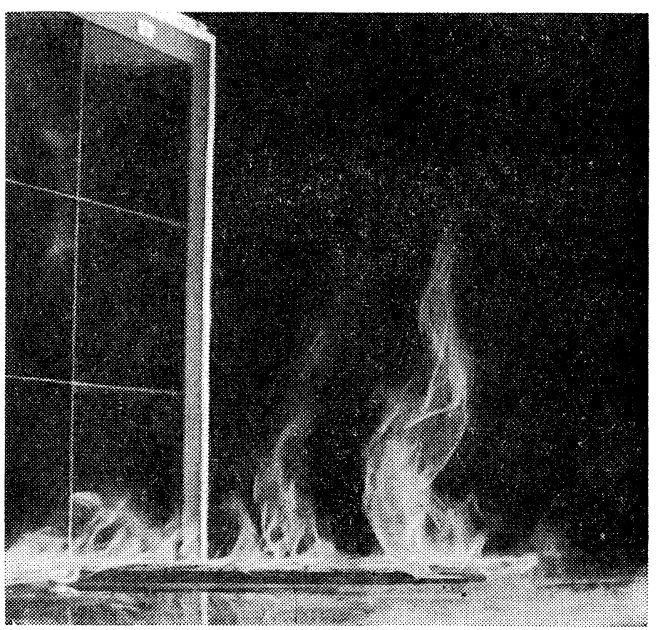

Plate 6 (b): Side view of whirl flames which generated by the movement of vortex column into the burning area. 


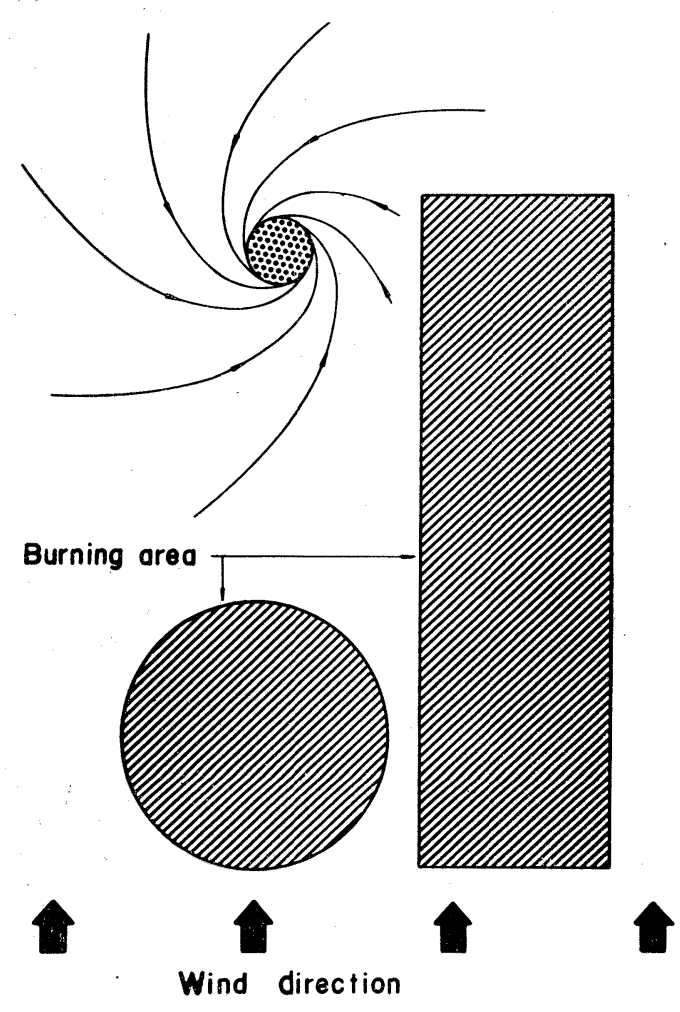

Fig. 7 Relative position between the site of vortex column and the burning area in the case when the most remarkable vortex column generated.

与えるものである。しかしながら，これと断定す るには，まだ検討すべき問題がいくつか残されて いる。その中で，もつとも問題だと思われるもの は，これまでに，大火と称せられるものが何回か あったにも拘らず，そのさい必ずしも竜巻が起つ ていないことである。被服廠跡の竜巻が広域大火 災によるとするならば，この疑問に一応答えてお かなければならない。しかし，この問題はむずか しく，これに具体的に答えるためには，長い研究 日時を要するであろう。ただ一つ考えられること は, 大火沉いろいろの種類があつて, 竜巻の伴 ない易いものと，そうでないものがあるといらこ とである。

過去の大火の資料を当つて見ると，大多数治 風がその主因となつている。昭和 9 年 3 月 21 日函 館市の大半を焼失させた大火の際は, 最大 22.0 $\mathrm{m} / \mathrm{s}$ の烈風が吹いていた。また，昭和15年 1 月 15 日静岡市の大火では $9.2 \mathrm{~m} / \mathrm{s}$ の風速であり, 決し て弱いものではなかつた。古い資料であるが，江 戸の三大大火と称せられる大火は, 何れも強風が 主要原因となつていた。これらに共通しているこ とは, 出火点が一つであつたことである。一点か ら出火した火災が強風に焻られて, 広域大火災に 発展していつた。このさいの焼失区域を見ると， 線状に伸びているのが特徴である(第 8 図)。

しふし，震災時の火災はこれらと全く異なつた 延燒形状を示す。すなわち, 出火点が数多くあつて, 広い面積にわたつてそれらが同時に燃えあがり, 広 域大火災となっている。和歌山市の空襲火災も，これと同じ延焼形状であつた。大別すると大火災には， 強風のため, 線状に延焼地帯が伸びて大火になる場合と, 同時多発火災によつて広く大火に 発展する場合 の二種類あることになる。広い地域が焼失する点で結果的には同じであるが，大火に発展するプロセスが 異なる。そして竜巻が発生するのは後者の場合に多いと考えられる。

なお，広域の同時多発火災でも，竜巻現象が見られなかつた注目すべき例が一つある。昭和 20 年 3 月 10 日夜, 現在の隅田区一帯が大空襲によつて，関東大震災を上回るほどの大火災になつた。そのさいに竜巻 が発生したといら記録も見当らないし，風聞も聞かない。充分調べた訳ではないので，断定的なことは述 べられないが, 竜巻が発生しなかつたのは, 当夜, 平均風速 $12.5 \mathrm{~m} / \mathrm{s}$ の強風が吹きつのつていたためと 考えられる。少なくと，円型燃焼板による火災実験からの推測ではそらなる。因に，被服廠跡で竜巻が発 生した時の風速は, 品川予警報信号所の観測では, 南々東 $4 \sim 5 \mathrm{~m} / \mathrm{s}$ であつた。和歌山市の空襲火㷋で竜 巻が発生した時も，風速は 2 3m/s 程度の風であつた。円型燃焼板の実験の項で，適度な風速の場合に竜 巻が発生するという表現を用いたが，自然風の場合に，これに相当する風速は 2 つような值であろう。

\section{VIII. むすび}

以上述ベた処から，被服颜跡を襲つた竜巻注大地震に伴つて発生し広域大火災が 主因となつて生じたも 
のと考えられる。不連続線の存在は竜巻発生の補 助的な役割を演じたかも知れないが，主因と呼ば れるほどのものではなかつた。この意味からすれ ば，被服廠跡を襲つた強風現象は，やはり，火災 旋風之称せられる心゙きものであろう。火災旋風の 発生に同時多発の広域大火災といら条件が決定的 に重要であることは, 和歌山市の事例が明白に証 明している。これに次いで火災旋風の要因になる ものは風速が適度であること，大気成層が不安定 であること等である。また，火災の延焼形状も火 災旋風発生の大きな要因である。とりわけ，周辺 が広範囲に火災域で取り圈まれた処では，火災旋 風発生の可能性は大きい。

火災旋風の重要な特徽は火災域周辺に強風と火 の粉をもたらすことである。これによつて，火災 の延焼域は急速に拡大され，場合によつては，そ の場を一瞬の間に火の海と化すことがある。

資料を当つて見ると, 大規模な火災旋風の起こ つた例は外国にも二，三みられる。しかしなが ら，火災旋風が発生して，一瞬の間に数百人ある いは数万人が焼死したという例はわが国だけにし か見られない。その理由はいろいろ考えられる が, 要は, 避難民の密集した広場に火災旋風が発

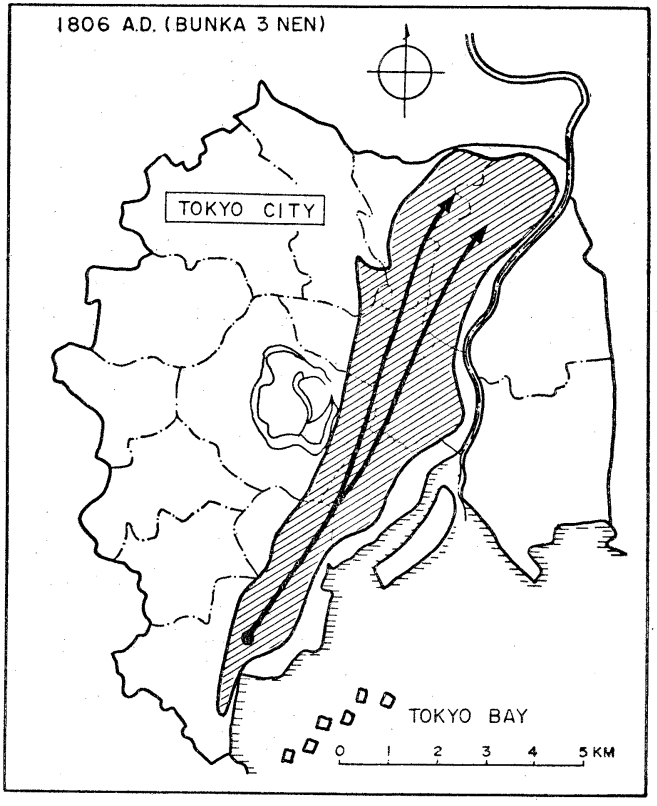

Fig. 8 An example of the greatest fire in the Tokugawa period, the fire broke out at one point and spread in a long and narrow pattern toward the lee because of being fanned by high wind.

生したためである。

本研究には，林陽生氏の協力を得た。付記して謝意を表す。

\section{文献}

中央気象台編 (1924) : 関東大震災調查報告 (気象編). pp. 1-61.

Dessens, J. (1962) : Man-made tornadoes, Nature, Jan. 6, Vol. 193, pp. 13-14.

藤原咲平 (1925) : 横浜の旋風. 震災予防調查会報告, 第100号成, pp. 275-280.

LEE, S. L. (1972) : Fire research. Applied Mechanics Review, May, Vol. 25, No. 5, pp. 503509.

中田金市編 (1969)：火災. 共立出版社, p. 626.

奥田 穣 (1973): Private communication による.

寺田寅彦(1925)：大正12年 9 月 1 日, 2 日の旋風について。震災予防調查会報告, 第 100 号戊, pp. 185-227.

和歌山市役所 (1956)：和歌山市戦災史. pp. 30-40.

(1975年 4 月 9 日受理) 